\title{
JAROG DAN KOJA, KANTONG KHASBADUY MAMPU MENINGKATKAN EKONOMI PENGRAJINNYA
}

\author{
JAROG AND KOJA, THE TRADITIONAL POUCH OF BADUY, \\ IN INCREASING THE CRAFTSMEN' ECONOMY ABILITY
}

\author{
Yudi Putu Satriadi \\ Balai Pelestarian Nilai Budaya Jawa Barat \\ Jl. Cinambo No. 136 Ujungberung-Bandung \\ e-mail: yuputsatriadi@gmail.com
}

\begin{abstract}
Abstrak
Penelitian mengenai jarog dan koja, kantong khas Baduy ini membahas tentang sistem ekonomi pengrajin jarog dan koja. Penelitian yang dilakukan untuk mendapatkan gambaran tentang proses produksi sampai dengan peran aspek budaya dalam pembuatan jarog dan koja. Penelitian ini bersifat deskriptif dengan metode kualitatif, dengan tahapan kerja meliputi: studi pustaka, wawancara, dan observasi. Hasil penelitian menunjukkan bahwa proses pembuatan jarog dan koja seluruhnya masih menggunakan pola tradisional sesuai dengan yang diwariskan oleh para orang tua sebagai pendahulu pembuatan jarog dan koja. Bahan yang digunakan berupa kulit pohon teureup yang dikeringkan dan dipilin menjadi tali kecil untuk dijalin menjadi kantong. Terjadi perluasan fungsi jarog dan koja. Kini, jarog dan koja bukan sekadar kantong untuk membawa keperluan sehari-hari orang Baduy melainkan menjadi cinderamata yang memiliki nilai ekonomis karena dibeli oleh orang luar Baduy.
\end{abstract}

Kata kunci: jarog, koja, kantong baduy, ekonomi, pengrajin.

\section{Abstract}

Research on the Jarog and Koja, typical Baduy pouch, is about the economic system of Jarog and Koja craftsmen. This research carries out to get an overview of the production process up to the role of cultural aspects in the Jarog and Koja manufacture. It is a descriptive study with qualitative methods with the phases of work includes literature review, interviews, and observations. The results showed that the entire manufacturing process of Jarog and Koja still use the traditional pattern in accordance with ancestors' inherit as a precursor of Koja and Jarog manufacture. The material used is dried teureup bark (Artocarpus elasticus) and twisted into small a rope and woven become bags. There is an expansion of Jarog and Koja function. Now, Jarog and Koja are not only a bag to carry groceries but also souvenir of Baduy that has economic value because it was purchased by the outer of Baduy.

Keywords: jarog, koja, baduy pouch, economic, craftsmen.

\section{A. PEN DAHUlUAN}

Salah satu misi Kementerian Pendidikan dan Kebudayaan, Dirjen Kebudayaan Tahun 2015 dalam melestarikan dan mengembangkan kebudayaan dan kebahasaan melakukan upaya peningkatan apresiasi pada seni dan karya budaya Indonesia sebagai bentuk kecintaan pada produk-produk dalam negeri; dan melestarikan, mengembangkan, dan memanfaatkan warisan budaya sebagai gambaran jati diri bangsa serta memanfaatkan untuk kesejahteraan rakyat. 
Tampak jelas arah misi Kementerian Pendidikan dan Kebudayaan, yaitu mengarah pada pemberdayaan produkproduk dalam negeri yang merupakan warisan budaya. Pemberdayaan memiliki makna yang mengarah pada penyejahteraan masyarakat melalui peningkatan nilai ekonomi pada produkproduk dalam negeri yang merupakan warisan budaya. Warisan budaya Indonesia merupakan salah satu potensi Indonesia yang perlu diberdayakan. Di Indonesia produk dalam negeri yang sekaligus merupakan warisan budaya sangat banyak jumlahnya, hampir diwakili oleh setiap suku bangsa atau komunitas adat yang tersebar di seluruh di Indonesia.

Salah satu komunitas adat yang memiliki warisan budaya di Indonesia, yakni di Provinsi Banten yaitu penduduk Kanekes Panamping atau dikenal juga dengan Baduy Luar. Ade M.K menyebutkan bahwa komunitas adat selalu terkait dengan kekentalan tradisi untuk melangsungkan tatanan kehidupan. Konsep dan kriteria komunitas adat adalah: Suatu kesatuan yang dalam melangsungkan interaksi sosialnya melibatkan hubungan yang intensif dengan frekuensi yang sangat tinggi sehingga hubungan sosialnya bersifat tatap muka (face to face), kuat dan kokoh menjalankan tradisi; hubungan sosial berdasarkan ikatan kekeluargaan, ikatan persahabatan yang erat, mengarah pada perasaan "kekitaan" bagi segenap warganya, dan motivasinya bercorak afektif; serta terdapat penyeragaman kesatuan tempat tinggal, fisik rumah, dan aturan (Intani, 2013: 69).

Warisan budaya yang mereka miliki yaitu kantong khas bernama jarog dan koja. Semula kantong ini mereka gunakan sendiri sebagai alat untuk menyimpan barang dan makanan saat pergi ke kebun atau huma, atau ke tempat lain. Jarog dan koja memiliki kelebihan yakni dapat membawa barang atau makanan yang cukup banyak. Jalinan tali yang terdapat pada jarog dan koja membuatnya dapat berlaku elastis.
Sebagai sebuah warisan budaya, kerajinan jarog dan koja masih bertahan dengan segala kekhasannya dan telah menjadi salah satu aktivitas ekonomi penduduk Baduy Panamping. Hal itulah yang menjadikan alasan dilakukan penelitian tentang jarog dan koja dikaitkan dengan sistem ekonomi.

Untuk mengarahkan penelitian tersebut diperlukan kerangka berpikir yang berupa konsep-konsep tentang kebudayaan, wujud kebudayaan, kerajinan tradisional, dan sistem ekonomi. Konsepkonsep tersebut diharapkan dapat menjadi pedoman dalam melakukan analisis pada penelitian ini.

Konsep kebudayaan yang dikemukakan oleh Melville J. Herkovits dan Bronislaw Malinowski menyebutkan bahwa kebudayaan adalah segala sesuatu yang terdapat pada masyarakat ditentukan oleh kebudayaan yang dimiliki oleh masyarakat itu atau yang disebut dengan cultural-determinism, yaitu kepastian kebudayaan pada masyarakat tertentu. Kebudayaan dipandang sebagai sesuatu yang turun-temurun dari satu generasi ke generasi lain, yang kemudian disebut sebagai superorganik. Mengenai wujud kebudayaan, disebutkan memiliki empat unsur pokok, yaitu: (a) alat-alat teknologi; (b) sistem ekonomi; (c) sistem keluarga; dan (d) sistem kekuasaan politik (Saebani, 2012: 162-163).

Konsep wujud kebudayaan dikemukakan oleh Koentjaraningrat paling sedikit berupa tiga wujud, yaitu:

1. Wujud kebudayaan sebagai suatu kompleks dari ide-ide, gagasan, nilainilai, norma-norma, peraturan-peraturan dan sebagainya.

2. Wujud kebudayaan sebagai suatu kompleks aktivitas kelakuan berpola dari manusia dalam masyarakat.

3. Wujud kebudayaan sebagai bendabenda hasil karya manusia (1990: 5).

Wujud pertama dari kebudayaan sifatnya abstrak, tidak dapat diraba atau difoto. Wujud kedua dari kebudayaan yang sering disebut sistem sosial, mengenai 
kelakuan berpola dari manusia itu sendiri. Wujud ketiga dari kebudayaan disebut kebudayaan fisik, dan memerlukan keterangan banyak, karena merupakan seluruh total dari hasil fisik dari aktivitas perbuatan, dan karya semua manusia dalam masyarakat, maka sifatnya paling konkret dan berupa benda-benda (Koentjaraningrat, 1990: 5).

Pendekatan kebudayaan yang dinilai memiliki relevansi dengan penelitian mengenai sistem ekonomi pengrajian jarog dan koja adalah pendekatan fungsional. Ade M. K. berpendapat bahwa pendekatan fungsional adalah pendekatan yang melihat kebudayaan sebagai benda-benda hasil karya manusia, alat-alat, benda-benda atau ide dan simbol. Dalam konteks ini, kebudayaan adalah proses dinamis dan produk yang dihasilkan dari diri manusia dan lingkungannya untuk mencapai pemenuhan hidup dan keselarasan sosial di dalam masyarakat (Andayani, 2013: 7).

Pendekatan fungsional pun dikemukakan oleh Malinowski bahwa fungsi diwajibkan untuk memenuhi kebutuhan (needs), karena fungsi menjadi sesuatu yang melayani kehidupan dan kelanjutan hidup (Rusnandar, 2015: 85).

Kerajinan tradisional adalah kerajinan atau hasil karya yang cara pengerjaannya dilakukan oleh seseorang atau satu kelompok masyarakat melaui keterampilan tangan, dengan pewarisan keterampilan disampaikan secara turuntemurun dan diterima oleh umum. Dalam Kamus Besar Bahasa Indonesia (KBBI) disebutkan bahwa kerajinan adalah barang yang dihasilkan melalui keterampilan tangan (2013: 1134). Dari berbagai penggunaan kata "tradisional" ketika digunakan dalam berbagai konteks, "tradisional" dapat berarti (a) diwarisi; (b) lama; (c) dari masa lampau; (d) dari nenek moyang; (e) sederhana; (f) tidak formal (Ahimsa-Putra, 2007: 11).

Hampir semua kerajinan tradisional diklasifikasikan sebagai seni kriya. Penentuan satu benda menjadi satu seni kriya harus memenuhi beberapa kriteria yang ketat. Biantoro menyebutkan bahwa benda kriya atau craft adalah benda yang dibuat dengan keterampilan dan ketekunan tinggi, dengan menitikberatkan pada aspek keindahan objek dan fungsi objek. Keterampilan yang diterapkan pada objek atau karya merupakan hasil dari pengulangan secara terus menerus bahkan sampai diturunkan kepada generasi setelahnya. Keterampilan dalam membuat objek kriya dapat diturunkan karena sebuah objek kriya memiliki keajegan pada setiap proses pembuatan maupun hasil akhir (2013:73). A. Darminto menyebutkan seni kriya tiada lain adalah karya seni terapan. Penciptaannya dilakukan dengan kesadaran, dengan menitikberatkan pada keindahan, dikerjakan oleh perorangan secara telaten untuk dipakai atau dipergunakan dalam kehidupan sehari-hari (1987: 1).

Dalam menghasilkan sesuatu, manusia tidak lepas dari penggunaan alat dan cara yang disebut dengan teknologi. Cateora menyebutkan bahwa teknologi menyangkut cara-cara atau teknik memproduksi, memakai serta memelihara segala peralatan dan perlengkapan. Masyarakat kecil yang berpindah-pindah atau masyarakat pedesaan yang hidup dari pertanian paling sedikit mengenal delapan macam teknologi tradsional, yaitu: (a) alatalat produksi; (b) senjata; (c) wadah; (d) alat-alat menyalakan api; (e) makanan; (f) pakaian; (g) tempat berlindung dan perumahan; dan (h) alat-alat transportasi (Saebani, 2012: 174-175).

Kerajinan tradisional seperti jarog dan koja, sekalipun masih bertahan di zaman modern ini, teknologi yang digunakan masih berupa teknologi tradisional. Menurut Ahimsa-Putra, kata tradisional dalam teknologi tradisional sama maknanya dengan makna "tradisional" dalam "kesenian tradisional". Teknologi tradisional biasanya juga diartikan sebagai "teknologi lama" dari suatu masyarakat, "teknologi dari para nenek moyang". Oleh karena jenis teknologi seperti ini umumnya belum 
kompleks, maka "teknologi tradisional" juga sering dikatakan senagai "teknologi sederhana”. Istilah ini sebenarnya kurang tepat, karena teknologi lama ada juga yang sudah kompleks, dan "kompleksitas" itu sendiri bersifat relatif, namun dalam wacana sehari-hari penyamaan tersebut sering kita temukan (2007: 11). Berbeda dengan teknologi modern, Ahimsa-Putra menyebutkan bahwa modern berarti masa kini, kontemporer. Sesuatu yang modern diartikan sesuai dengan masa kini atau berasal dari masa kini (Intani, 2013: 187).

Kaitannya dengan pertahanan ekonomi pengrajin jarog dan koja, perlu diuraikan pula tentang konsep sistem ekonomi. R.Firth mendefinisikan sistem ekonomi atau sistem mata pencaharian sebagai seluruh perilaku manusia dalam organisasi dan pranata yang mengatur penggunaan sumber-sumber yang terbatas untuk memenuhi kebutuhan dalam suatu masyarakat tertentu (Koentjaraningrat, 1990: 175). Sistem ekonomi adalah satu aturan atau tata cara untuk mengatur perilaku masyarakat dalam melakukan kegiatan ekonomi untuk meraih satu tujuan $^{1 .}$ M.J. Herskovits menyebutkan bahwa sistem ekonomi atau mata pencaharian hidup tidak semata-mata ditinjau dari segi teknologinya melainkan dari pola-pola aktivitas dan interaksi yang menguasai proses produksi, distribusi, dan konsumsi (Harsojo, 1982: 235).

Permasalahan dalam penelitian ini adalah (1) Bagaimana pola produksi, pola distribusi, dan pola konsumsi pengrajin jarog dan koja di Kanekes Panamping, Banten; (2) Aspek budaya apa yang menyertai aktivitas-aktivitas tersebut. Adapun tujuan penelitian adalah (1) untuk mengetahui tentang pola produksi, pola distribusi, dan pola konsumsi para pembuat jarog dan koja; dan (2) untuk mengetahui aspek budaya yang menyertai ketiga aktivitas tersebut.

Ruang lingkup penelitian meliputi ruang lingkup materi dan wilayah. Ruang lingkup materi dibatasi pada berbagai aspek yang melatarbelakangi penelitian, seperti asal-usul jarog dan koja, bahan pembuat jarog dan koja, pola produksi, pola distribusi, dan pola konsumsi para pembuat jarog dan koja; serta aspek-aspek budaya yang menyertai ketiga aktivitas tersebut. Ruang lingkup wilayah dibatasi di wilayah Kanekes Panamping.

\section{B. METOdE PENELITIAN}

Penelitian tentang sistem ekonomi pengrajin jarog dan koja di Kanekes Panamping merupakan jenis penelitian kualitatif. Metode penelitian kualitatif adalah metode penelitian yang digunakan untuk meneliti pada kondisi objek yang alamiah (sebagai lawannya adalah eksperimen). Bahwa peneliti adalah sebagai instrumen kunci, teknik pengumpulan data secara triangulasi (gabungan). Analisis data bersifat induktif, dan hasil penelitian kualitatif lebih menekankan makna daripada generalisasi (Saebani, 2012: 73).

Penelitian bersifat deskriptif. Menurut Sutrisno Hadi, pada taraf deskriptif, peneliti hanya melukiskan keadaan objek atau peristiwanya tanpa mengambil kesimpulan yang berlaku secara umum (Saebani, 2012: 66). Teknik pengumpulan informasi dilakukan dengan wawancara mendalam terhadap tokoh masyarakat lokal dan para pengrajin (Rusnandar 2015: 99). Metode pengamatan juga tepat digunakan untuk sasaran penelitian mengenai perilaku/tindakan dan benda (Kasnodihardjo, 1992: 18).

Tinjuan pustaka dilakukan untuk menunjukkan adanya perbedaan antara tulisan ini dengan tulisan lain yang juga membahas tentang sistem ekonomi. Dengan demikian melalui tinjauan pustaka dapat menunjukkan kelayakan mengapa tulisan ini diangkat. Salah satu yang ditinjau adalah tulisan tentang "Sistem Ekonomi Pengrajin Kelom Geulis di Gobras, Kota Tasikmalaya, Provinsi Jawa Barat" oleh Ria Andayani Somantri, yang juga menjadi referensi untuk penelitian ini.

Tulisan tersebut menyampaikan beberapa hal, yakni bahwa gagasan kelom 
geulis muncul di Tasikmalaya sekitar tahun 1950-an atas inisiatif seorang buruh sandal yang bekerja di Bandung. Bahan utama kelom geulis yaitu beberapa jenis kayu tertentu yang sudah tua. Kini jenisjenis kayu tua sudah jarang didapat. Kebanyakan pohon kayu ditebang selagi muda untuk kebutuhan bangunan. Lain halnya dengan jarog dan koja. Bahan utama jarog dan koja adalah kulit pohon teureup yang tersedia di lingkungan sekitar mereka.

Tahapan panjang yang dilakukan dalam pembuatan kelom geulis mulai dari kayu gelondongan hingga menjadi kelom geulis menyebabkan ketidakseimbangan antara penghasilan dari hasil penjualan dengan waktu yang diperlukan dalam pembuatan satu kelom geulis. Kondisi ini menyebabkan kaum muda jarang meminati bidang pengerjaan kelom geulis. Hal ini pula yang menyebabkan keberadaan kelom geulis tidak sebanyak masa lalu.

Hingga saat ini jarog dan koja keberadaannya masih dapat disaksikan pada masyarakat Kanekes, terutama Kanekes Panamping. Kehadiran jarog dan koja hingga saat ini tidak lepas dari fungsi jarog dan koja yang erat dalam kehidupan mereka. Mengingat kekuatan fungsi dari jarog dan koja dalam kehidupan mereka, maka setiap anggota keluarga diharuskan mampu membuat jarog dan koja. Kini, jarog dan koja bukan hanya kebutuhan keluarga sebagai alat untuk membawa makanan dan peralatan ke huma, melainkan memiliki nilai jual kepada orang di luar Kanekes Panamping yang mereka beli sebagai cenderamata.

Tampak bahwa penelitian ini berbeda dengan tulisan Andayani, yang ditunjukkan secara jelas pada fungsi kriya bagi masyarakat pendukungnya masingmasing. Persoalan fungsi ini memiliki keterkaitan yang erat dengan gagasan awal, dengan pengadaan bahan, dan dengan keberlangsungan kriya itu sendiri. Dengan demikian baik itu sistem produksi, distribusi, maupun konsumsinya akan sangat berbeda.

\section{HASIL DAN BAHASAN}

Masyarakat Urang Tangtu/Urang Kajeroan yang disebut oleh masyarakat luar sebagai Baduy Dalam dan Urang Panamping yang disebut oleh orang luar sebagai Baduy Luar menempati wilayah Desa Kanekes Kecamatan Leuwidamar Kabupaten Lebak Provinsi Banten. Urang Tangtu, menempati tiga kampung yakni 1) Kampung Cikeusik, 2) Kampung Cibeo, dan 3) Kampung Cikertawana. Urang Panamping, menempati wilayah-wilayah di luar ketiga kampung tersebut.

Kedua kelompok masyarakat Baduy tersebut memiliki peran dan fungsi yang berbeda. Termasuk dalam tugas hidup yang terimplikasi pada pola perilaku anggota kelompoknya. Masyarakat Urang Tangtu dikatakan sebagai orang yang diberi tugas untuk bertapa, tentu memiliki sifat tersendiri sesuai dengan tugas yang diberikan. Tata kehidupan mereka sepenuhnya bertumpu pada filosofis tetap pada peninggalan para leluhur yang telah teruji dan mendarah daging. Lain halnya dengan Urang Panamping, mereka ditugaskan oleh adat untuk menjaga orang yang sedang bertapa (Urang Tangtu). Tata kehidupan mereka sedikit berbeda dengan Urang Tangtu. Ikatan adat mereka lebih longgar dibandingkan dengan Urang Tangtu.

Tugas Urang Panamping tersebut berpengaruh pada berbagai aspek kehidupannya, terutama dalam aspek perilaku serta sistem sosialnya. Mereka lebih terbuka dibandingkan dengan Urang Tangtu. Sikap ini terbentuk karena mereka berhadapan langsung dengan faktor-faktor yang datang dari luar setiap saat. Faktorfaktor tersebut antara lain, semakin pesatnya perkembangan ilmu pengetahuan dan teknologi.

Urang Tangtu lebih sering membawa peralatan atau barang lainnya dengan menggunakan kain segi empat (iket) yang diikatkan ujung-ujungnya hingga menjadi kantong yang disandang. Berbeda dengan Urang Tangtu, Urang Panamping kerapkali menggunakan jarog 
atau koja sebagai alat untuk membawa barang atau peralatan, baik ke huma atau ke tempat lain bahkan dapat juga digunakan sebagai tempat membawa ikan kala mereka mengambil ikan di sungai.

Pemberdayaan jarog dan koja serta cinderamata lainnya khas Baduy dari kebutuhan alat sehari-hari menjadi cinderamata telah mampu mengangkat perekonomian masyarakat Baduy, khususnya pengrajin jarog dan koja, kebanyakan orang Baduy Panamping. Gambaran kemampuan ekonomis para pengrajin tersebut dilihat dari jumlah kepemilikan leuit beserta isinya. Uang yang diperoleh dari hasil penjualan cinderamata tersebut, berupa keuntungan bersih karena tidak dipotong modal kerja dan bahan baku. Uang tersebut dapat digunakan untuk berbagai keperluan yang tidak bertentangan dengan ketentuan adat, di antaranya untuk menyewa huma. Dengan panambahan luas huma yang digarap akan memperoleh hasil padi yang lebih banyak dibandingkan hanya menanam padi di huma miliknya. Selain untuk menyewa huma, uang tersebut dapat digunakan untuk membeli beras untuk memenuhi kebutuhan makan sehari-hari, sehingga padi di leuit tidak cepat habis bahkan diusahakan tetap bertahan dalam jumlah tetap. Tidak mengherankan, saking hematnya seorang pemilik leuit, memiliki padi yang berusia puluhan tahun. Kapasitas leuit yang terbatas akibat padi yang tersimpan tidak pernah berkurang karena tidak digunakan, dapat memaksa seorang penduduk Baduy Panamping, yakni pengrajin jarog dan koja untuk mendirikan leuit baru. Penambahan jumlah leuit yang dimiliki penduduk tersebut serta penuhnya terisi padi tiap-tiap leuit mencerminkan jumlah kekayaan yang dimiliki seseorang. Kelak, ketika pemilik leuit meninggal dapat mewariskan leuit yang terisi penuh oleh padi kepada anakanaknya sebanyak mungkin. Cara-cara mewariskan leuit beserta isinya merupakan cita-cita para orang tua dalam menjamin kesejahteraan anak-anak mereka.
Kelebihan uang yang diperoleh dari hasil penjualan jarog dan koja tidak mungkin mereka gunakan untuk membangun rumah dengan bahan dan bentuk yang berbeda dengan rumah lainnya, atau digunakan untuk membeli pakaian dan perhiasan yang berbeda dengan pakaian dan perhiasan penduduk pada umumnya. Hal tersebut merupakan yang ditabukan dalam kehidupan masyarakat Baduy.

\section{A sal-usul Jarog dan Koja}

Menurut Suhada, kerajinan tangan yang dibuat oleh Urang Panamping adalah jarog dan koja, menenun kain untuk samping (celana Urang Tangtu), selendang, kain sarung khas Baduy, tempat air dari buah kukuk yang dikeringkan, serta peralatan pertanian seperti parang, golok, pisau, kored, dan yang lainnya. Hasil kerajinan tangan tersebut mereka jual di pasar terdekat atau dijajakan di depan rumah pada saat wisatawan berkunjung, dengan harga yang bervariasi (2003: 25). Bahkan dari cara menjalin bahan kulit pohon teureup, muncul modifikasi kerajinan lain, seperti tempat botol air mineral, dompet telepon genggam, dan hiasan lainnya.

Tas atau kantong khas Baduy yang dibuat dengan cara dijalin ada dua macam, yakni jarog dan koja. Hal yang membedakan kedua barang tersebut adalah bentuk talinya. Tali untuk menyandang pada koja hanya satu sedangkan tali penyandang pada jarog berjumlah dua. Dengan jumlah tali yang berbeda, kekuatan saat disandang antara kedua tas tersebut berbeda. Jarog memiliki kekuatan lebih kuat dibanding koja saat disandang. Penampang atau ruangnya pun dibuat lebih besar daripada koja. Oleh sebab itu, jarog dapat digunakan untuk membawa barang yang banyak dan berat.

Barang-barang hasil kerajinan tangan tersebut mereka kenal, mereka miliki dan mereka pakai dalam kehidupan sehari-hari sesuai dengan peruntukannya. Namun mereka, tidak tahu tentang asal- 
usul atau riwayat keberadaan barangbarang tersebut, selain cara perolehannya. Mereka hanya mengetahui bahwa jarog dan koja sudah ada sejak dulu. Sejak mereka kecil sudah melihat jarog dan koja yang dipakai oleh orang-orang di Baduy Panamping.

Jika melihat bahan yang digunakan, proses pengadaan bahan baku, dan waktu pembuatannya, dapat diperkirakan bahwa jarog dan koja sudah ada sejak orang Baduy ada, khususnya orang Baduy Panamping. Bahan yang dipergunakan untuk membuat jarog dan koja berupa kulit pohon teureup. Pohon teureup merupakan pohon yang tumbuh liar dan banyak terdapat di sekitar hutan tempat tinggal mereka. Proses pengadaan bahan baku dengan cara dikeringkan menggunakan sinar matahari lalu disuwir (disobek-sobek menjadi bagian kecil) dan selanjutnya dipilin menjadi tali-tali kecil. Kebiasaan atau keterampilan memilin merupakan keterampilan yang sudah dikuasai oleh orang-orang dahulu, sama halnya seperti memilin rokok yang terbuat dari daun enau kering.

Dikaitkan dengan waktu pembuatan jarog dan koja, Dinas Inkosbudpar Lebak menuliskan bahwa pembuatan jarog dan koja dibuat sambil menunggu datangnya waktu panen (biasanya 6 bulan), selain menenun dari hasil panenan kapas yang ditanam sendiri dengan warna hitam, biru tua dan putih untuk bahan baju dan untuk kain sarung (2004: 42). Artinya jarog dan koja sudah dibuat oleh penduduk Baduy bersamaan dengan adanya sistem menanam padi di huma.

Mereka memperkirakan keberadaan jarog dan koja tersebut karena dorongan kebutuhan orang-orang, khususnya Baduy Panamping dalam membawa bekal makanan atau peralatan saat mereka bepergian atau pergi ke huma. Para penduduk dan bahkan pengrajin jarog dan koja pun tidak pernah menanyakan mengenai asal-usul jarog dan koja baik kepada orang tua mereka atau kepada kolot yang lain.

\section{Pola Produksi}

\section{a. Tenaga Kerja}

Berbicara pola produksi tidak dapat dilepaskan dari aspek-aspek yang menentukan munculnya satu barang. Aspek-aspek tersebut adalah tenaga kerja, peralatan dan bahan baku, serta proses pengerjaan barang tersebut.

Dalam menghasilkan jarog atau koja, tenaga kerja atau pembuatnya adalah penduduk Baduy Panamping yang berada di Kanekes. Tidak diketahui pasti Baduy Tangtu membuat jarog atau koja tersebut. Penduduk Baduy Tangtu kelihatannya lebih meminati membawa barang-barang dengan menggunakan iket atau kain segi empat lainnya yang diikatkan ujungujungnya daripada menggunakan jarog atau koja.

Tenaga kerja yang terlibat dalam pembuatan jarog dan koja biasanya satu keluarga dengan melibatkan anggota keluarga inti. Dari anggota keluarga yang terlibat, biasanya hanya satu atau dua orang yang memiliki keterampilan membuat jarog dan koja, anggota yang lainnya jika bisa pun tidak terampil. Keterampilan membuat jarog dan koja yang tidak merata di seluruh anggota keluarga disebabkan penurunan keterampilan kepada anak-anaknya tidak berdasarkan paksaan. Anak-anak yang meminati membuat jarog atau koja akan diajari secara sungguh-sungguh oleh orang tuanya. Hasilnya, tentu saja akan memiliki keterampilan yang lebih dibandingkan dengan anak-anak yang tidak meminati.

Dalam satu proses pembuatan jarog dan koja hampir dipastikan seluruh anggota keluarga terlibat dengan pembagian kerja yang berbeda-beda. Tiaptiap bidang pekerjaan yang dipegang oleh setiap anggota keluarga memerlukan pengetahuan dan keterampilan khusus. Bapak atau anak laki-laki yang sudah dewasa biasanya bertugas mengumpulkan kulit pohon teureup. Pekerjaan mengambil kulit pohon teureup dikerjakan oleh lakilaki dewasa. Sebabnya, jarak antara pemukiman dengan hutan tempat 
tumbuhnya pohon teureup yang relatif jauh hanya bisa ditempuh oleh laki-laki dewasa. Gangguan dan bahaya binatang buas serta binatang lainnya yang ada dalam hutan kerapkali mengancam pengambil kulit pohon teureup. Laki-laki dewasa dianggap mampu menanggulangi semua gangguan dan ancaman dari binatang ini.

Pekerjaan mengambil kulit pohon teureup memerlukan pengetahuan khusus dalam menentukan usia satu pohon teureup yang sudah cukup untuk diambil kulitnya. Rata-rata pohon teureup yang cukup umur untuk diambil kulitnya kali pertama berusia kira-kira satu setengah tahun. Begitu juga untuk pengambilan kulit pohon teureup selanjutnya. Untuk mengajarkan cara-cara mengambil kulit pohon teureup, seorang bapak atau kakak laki-laki dewasa sesekali mengajak pula anak atau adik laki-lakinya untuk ikut serta mengambil kulit pohon teureup.

Pohon teureup yang sudah diambil, begitu sampai di rumah, apabila sinar matahari cukup terik, maka akan langsung dijemur. Dengan cara seperti itu kulit pohon teureup akan cepat mengering dan dapat diproses ke tahapan selanjutnya.

Tugas untuk mengangkat kulit pohon teureup yang dijemur dapat dilakukan oleh anggota keluarga yang lain, tidak terbatas oleh usia dan jenis kelamin. Pekerjaan mengangkat kulit pohon teureup yang dijemur cukup mudah dan tidak mengandung resiko apapun. Caranya tinggal diangkat untuk disimpan di dalam rumah, dan siap untuk dijemur kembali esok harinya apabila masih belum kering. Apabila sudah kering dan tidak akan dijemur lagi, maka kulit pohon teureup tersebut digulung memanjang dan diikat agar tidak berantakan. Mungkin pekerjaan ini tidak dapat dilakukan oleh anak-anak yang masih kecil. Tugas mengikat ini biasanya dilakukan oleh anak-anak yang sudah besar, ibunya, atau bapaknya. Tugas mengangkat dan menggulung ini lebih diutamakan kepada anggota keluarga yang pada saat itu sedang senggang.
Pekerja yang menyobek kulit pohon teureup dari lembaran yang panjang menjadi bagian-bagian lebih kecil dapat dilakukan oleh seluruh anggota keluarga. Tetapi untuk menghasilkan sobekan yang tidak terlalu kecil atau terlalu pendek akan dilakukan oleh anggota keluarga yang mengerti ukuran sobekan yang bagus. Jika ukuran sobekan terlalu kecil dan pendek atau terlalu besar dan panjang akan menyulitkan dalam memilin kulit pohon teureup menjadi tali. Jika terdapat anakanak yang masih kecil ikut serta dalam menyobek kulit pohon, maka akan dibimbing tentang cara menyobek yang benar oleh kakak-kakaknya atau orang tuanya.

Pekerja yang ngarara (memilin) sobekan kulit pohon teureup harus memiliki keterampilan dalam memilin. Tali yang dihasilkan dari memilin harus rata besar bulatannya, tersambung kuat, serta terselesaikan secara cepat. Hanya orang-orang yang sudah terbiasa yang dapat dengan cepat dan benar mengerjakan pekerjaan ini. Biasanya yang dapat mengerjakan pekerjaan ini secara benar dan cepat adalah bapak, ibunya atau anakanak yang sudah dewasa. Untuk menghasilkan tali kulit yang rata besarnya maka diperlukan tekanan ibu jari pada kulit pohon yang dipilin. Hasil pekerjaan anakanak dalam memilin, biasanya besaran talinya kurang merata serta sambungannya tidak kuat, dan kurang cepat dalam penyelesaian. Pekerja yang memilin akan langsung menggulung tali hasil pilinan manakala hasilnya sudah panjang.

Pekerja yang membuat jarog dan koja biasanya merupakan orang yang punya ketekunan dalam mengerjakan sesuatu. Penduduk Baduy Panamping yang dinilai dapat membuat jarog dan koja yang bagus biasanya kaum ibu. Rata-rata penduduk Baduy Panamping dapat membuat jarog dan koja, hanya ada yang biasa mengerjakan dan tidak biasa. Hasil yang diperoleh antara orang yang terbiasa membuat dengan yang tidak, tentu saja akan berbeda. Buatan orang yang tidak 
terbiasa membuat jarog dan koja hasilnya tidak terlalu bagus. Oleh sebab itu, hasil buatannya digunakan untuk keperluan sendiri. Bagi orang yang terbiasa membuat, dia akan membuat sebanyakbanyaknya. Hasilnya untuk dijual kepada orang yang membutuhkan, baik penduduk Baduy sendiri atau para tamu yang berkunjung ke daerah Baduy.

\section{b. Peralatan dan Bahan Baku}

Pembuatan jarog dan koja masih menggunakan teknologi tradisional. Peralatan yang digunakan berasal dari bahan bambu yang didapat dengan dibuat sendiri. Cara penggunaan alat tidak rumit, sehingga setiap orang dalam waktu singkat dapat menguasai penggunaan alat tersebut. Latihan yang terus-menerus diperlukan hanya untuk melatih kecepatan dalam penyelesaian jarog dan koja, bukan untuk kemahiran dalam penguasaan alat.

Peralatan yang digunakan dalam seluruh proses pembuatan koja dan jarog adalah:

1) Tiang untuk menancapkan paku pengait;

2) Golongan untuk menggulung tali kulit pohon teureup yang sudah dipilin;

3) Corokan, alat untuk menyimpan tali kulit pohon teureup yang akan dijeujeut (dijalin), sekaligus alat untuk menjalin; dan

4) Handepang, bilah kayu tipis yang digunakan untuk mengukur jarak jalinan.

Paku pengait diperlukan untuk mengaitkan tali kulit pada saat ngarara (memilin). Tali kulit perlu dikaitkan karena tali hasil memilin harus terus terbentang, tidak boleh kendur. Selain digunakan saat memilin kulit pohon menjadi tali, paku pengait ini pun digunakan pada saat ngajeujeut (menjalin) tali kulit pohon teureup menjadi sebuah jarog dan koja. Paku pengait ini ditancapkan pada tiang di bagian serambi depan rumah, dapat pula pada kusen pintu untuk keluar masuk rumah. Maksud menancapkan paku pada tiang-tiang ini, karena tiang-tiang atau kusen pintu rumah dinilai kuat untuk menahan bentangan tali kulit pohon teureup pada saat memilin atau membuat jarog dan koja. Selain itu, pada tiang bagian serambi serta tiang pada kusen pintu merupakan tempat yang paling terang terkena sinar matahari. Pekerjaanpekerjaan memilin dan menjalin memerlukan penerangan sinar matahari yang cukup agar tidak terjadi kesalahan, terutama pada saat menjalin. Tempat yang cukup terang adalah bagian luar rumah atau bagian yang menghadap ke arah luar. Bagian dalam rumah di Baduy pada umumnya agak gelap sekalipun pada siang hari karena tidak menggunakan alat penerangan. Penggunaan listrik untuk penerangan merupakan hal yang tabu di wilayah Baduy.

Paku pengait, ini sebenarnya mempunyai beberapa fungsi lain selain menjadi tempat pengait sewaktu memilin dan menjalin. Paku pengait yang berada di bagian serambi depan rumah sering digunakan untuk memajang koja atau jarog atau barang lainnya yang akan dijual.

Golongan, dikatakan golongan karena sesuai dengan fungsinya untuk menggulung tali kulit pohon teureup yang sudah dipilin. Jika tidak digulung, tali yang panjangnya bermeter-meter bisa kusut tidak beraturan. Dengan golongan, tali akan tersusun rapi, termasuk saat melepaskan tali untuk dijalin. Golongan dapat terbuat dari bahan apa saja, seperti kaleng kosong, botol, kayu, atau bambu. Para pengrajin lebih suka untuk membuat golongan dari bahan kayu atau bambu karena bahannya banyak tersedia dan cara membuatnya sangat mudah. Cara membuatnya yaitu dua bilah bambu atau kayu pipih berukuran panjang kurang lebih dua puluh sentimeter diikat atau dipaku tengah-tengahnya, sehingga membentuk alat seperti tanda tambah (+) atau tanda kali ( $\mathrm{x}$ ). Ujung tali awal hasil pilinan disimpan di tengah-tengah dan terus digulung jengkal demi jengkal. Dengan 
cara demikian tali hasil memilin tidak terjurai dan bisa kusut.

Corokan merupakan alat untuk menjalin tali kulit pohon teureup saat membuat jarog dan koja. Terbuat dari bambu pipih tebal dengan lebar sekitar 3-4 sentimeter dan panjang sekitar 10 sentimeter. Alat ini dibuat sendiri oleh pengrajin jarog dan koja. Selintas, bentuk corokan ini menyerupai ketepel dari bahan bambu. Ujung corokan bagian atas berbentuk lancip agak tumpul. di tengahnya diberi cowak, sedangkan ujung bawahnya memiliki rongga dan memiliki cowak. Melalui cowak-cowak itulah dimasukkan dan digulungkan tali kulit pohon teureup. Bentuk lancip agak tumpul, berguna untuk memudahkan memasukkan tali kulit pada rongga tali di sampingnya atau di atasnya. Pada saat menjalin, tali dari cowak-cowak itu dilepaskan dan dijalin dengan jalinan yang sudah ada. Tali-tali yang berada di corokan adalah hasil pemindahan dari golongan.

Handepang, merupakan alat ukur untuk jarak jalinan bagian atas dengan bawahnya. Alat ini terbuat dari bambu tipis bagian sembilu bambu dengan ukuran panjang sekitar dua puluh sentimeter dan lebar satu atau dua sentimeter. Cara penggunaannya adalah diletakkan pada bagian jarog dan koja yang sedang dijalin. Setiap akan menjalin, corokan akan dilintaskan melalui handepang. Dengan demikian jarak jalur pada koja dan handepang akan sama besarnya mengikuti ukuran handepang. Jika pengrajin menginginkan ukuran jarak yang lebih lebar atau lebih kecil, maka handepang akan ditukar bergantian sesuai dengan ukuran yang diinginkan. Handepang dibuat sendiri dengan cara membelah bambu sesuai dengan ukuran lebarnya, memotong bambu sesuai panjang yang diinginkan dan selanjutnya diratakan dengan cara diraut menggunakan pisau atau pisau raut.

Bahan baku pembuatan jarog dan koja hanya kulit kayu teureup yang dikeringkan. Setelah kulit kayu teureup kering, maka akan disuwir (disobek) menjadi bagian-bagian kecil. Bagianbagian kulit kayu teureup yang bentuknya kecil-kecil akan disambungkan dengan bagian tali yang sudah terpilin yang berada di atasnya. Cara menyambungkan yaitu dengan menempelkan serpihan kulit kayu pada tali yang sudah terpilin sambil terus dipilin. Hasil sambungan dan pilinan akan menjadi tali-tali kecil berdiameter kurang lebih satu milimeter. Jika tali-tali hasil memilin sudah cukup panjang, jengkal demi jengkal akan digulung pada golongan. Jika tidak digulung, tali yang terjurai akan mengganggu proses pemilinan. Dengan tali-tali kecil itulah jarog dan koja dibuat dengan cara menjalinkan satu tali dengan tali lainnya.

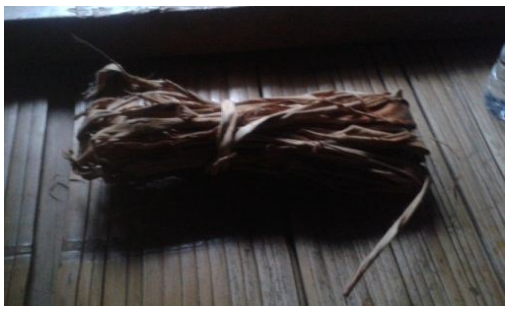

Gambar 1. Kulit Kayu Teurep Kering Sumber: Yudi P. Satriadi.

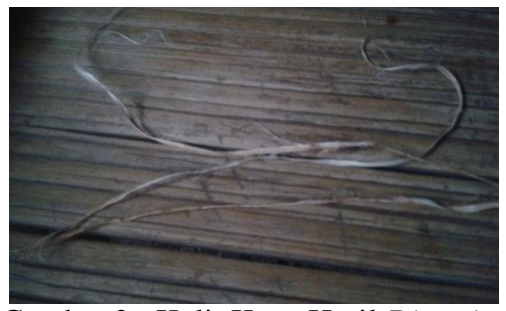

Gambar 2. Kulit Kayu Hasil Disuwir Sumber: Yudi P. Satriadi.

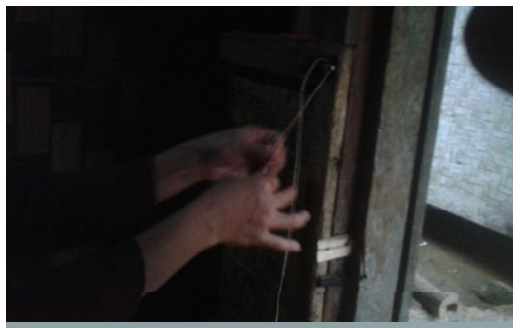

Gambar 3. Proses Memilin Sumber: Yudi P. Satriadi. 


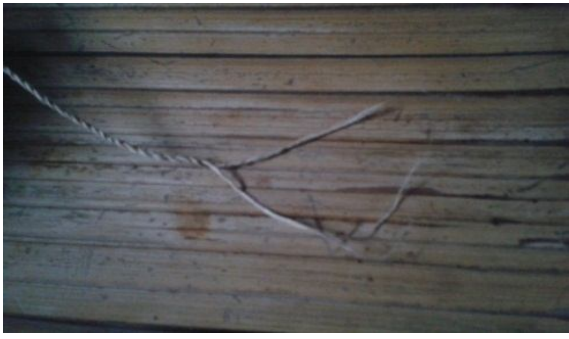

Gambar 4. Tali Hasil Memilin Sumber : Yudi P. Satriadi

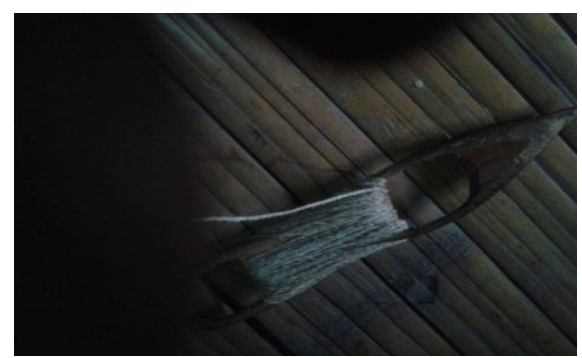

Gambar 5. Corokan Sumber: Yudi P. Satriadi.

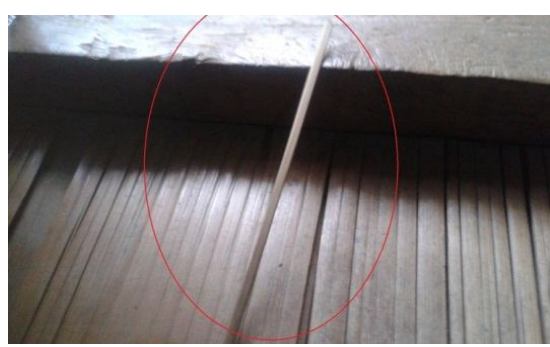

Gambar 6. Handepang Sumber: Yudi P. Satriadi.

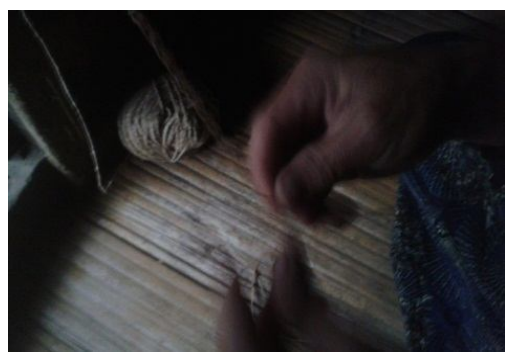

Gambar 7. Membuat Pegangan Sumber: Yudi P. Satriadi.

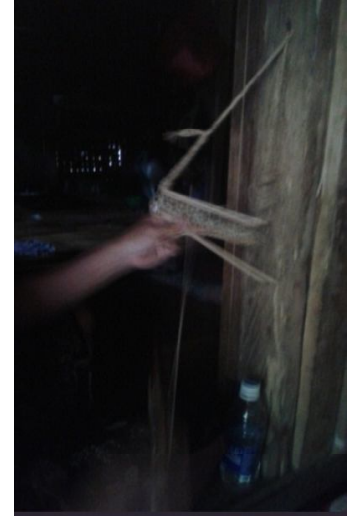

Gambar 8. Menjalin Jarog, Koja Sumber: Yudi P. Satriadi.

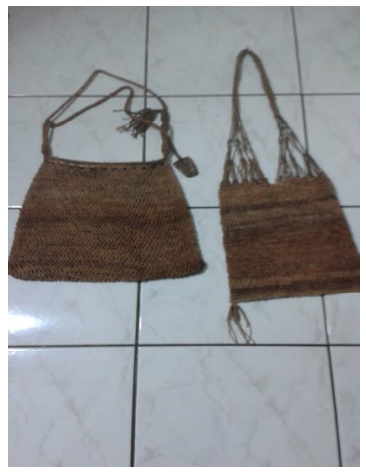

Gambar 9. Jarog,Koja

Sumber: Yudi P. Satriadi.

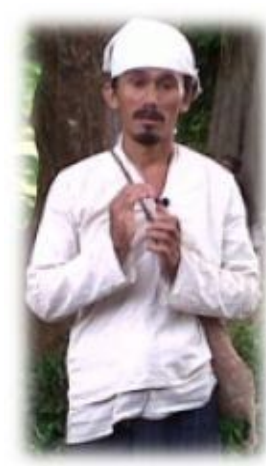

Gambar 10. Cara Menggunakan Jarog/Koja Sumber:

www.biem.co/read/2015/05/18/98/sebabaduy-2015-menjaga-lingkungan-denganbudaya.

\section{Proses Pembuatan}

Proses pembuatan jarog dan koja tidak lain menjalinkan tali-tali kulit kayu bagian vertikal dengan bagian horizontal. Bagian yang diletakkan secara vertikal 
dapat disamakan dengan posisi benang lusi pada kain tenun dan bagian horizontal dapat disamakan dengan kain pakan pada kain tenun. Untuk selanjutnya, guna mempermudah uraian tulisan, akan digunakan istilah tali lusi dan tali pakan.

Proses awal pembuatan jarog dan koja adalah menyediakan beberapa utas tali lusi kulit kayu. Tali yang disediakan diperuntukkan bagi bagian atas jarog dan koja yang berfungsi sebagai pegangan atau selendang. Jumlah utas tali kulit kayu yang disediakan rata-rata berjumlah lima belas utas. Setiap utas berukuran panjang sedepa orang dewasa. Jumlah ini menentukan kekerapan rongga pada badan jarog dan koja. Secara tidak langsung akan menentukan besar dan kecilnya bentuk jarog dan koja. Jumlah utas tali pada jarog akan lebih banyak daripada koja, karena pegangan untuk jarog berjumlah dua buah sedangkan pada koja satu.

Utas-utas tali lusi disamakan panjangnya dan dilipat menjadi dua bagian sama panjang. Agar tidak terberai, di tengah tali-tali diikat kuat menggunakan tali kulit yang pendek. Ikatan tali yang merupakan posisi tengah-tengah dari dua bagian tali dikaitkan pada paku pengait.

Pembuatan awal jarog dan koja dimulai dengan membuat bagian pegangan atau bagian yang akan diselendang. Proses pembuatan bagian ini dilakukan dengan cara menjalinkan tali kulit pakan yang berada dalam corokan dengan tali lusi yang dikaitkan pada paku pengait. Jalinan yang dibuat sangat rapat masing-masing berjarak setengah sentimeter. Setiap selesai menjalin, tali pakan akan diputus dengan gunting atau pisau. Hasil pekerjaan ini berupa kumpulan tali yang terikat dan mencirikan bagian sebuah pegangan atau bagian yang diselendangkan. Cara menjalin serupa terus dilakukan ke bagian bawah tali lusi sampai panjang tali pegangan dianggap cukup. Untuk "mematikan" bagian pegangan dengan bagian ini, dijalin kembali tali pakan dan lusi yang tidak terputus secara rapat.
Pekerjaan selanjutnya adalah membuat bagian badan jarog dan koja. Cara membuat bagian ini masih dengan cara menjalinkan antara tali lusi dan pakan. Bedanya antara jalinan untuk bagian pegangan dengan bagian badan adalah pada tali pakan yang berada pada corokan tidak diputuskan. Tali pakan terus dijalinkan pada tali lusi mulai dari bagian atas sampai kepada bagian bawah badan jarog dan koja dengan menggunakan pembatas handepang. Handepang yang digunakan merupakan pembatas ukuran lebar rongga sekaligus untuk meluruskan tiap jalinan. Apabila akan memperbesar atau memperkecil rongga jalinan digunakan ukuran handepang yang berbeda. Semakin besar lebar handepang yang digunakan, rongga yang dihasilkan akan semakin besar dan badan jarog dan koja akan semakin besar pula.

Akhir jalinan tali pakan dan lusi dilakukan pada bagian bawah badan jarog dan koja. Jalinan akan dimatikan pada semua bagian jalinan akhir apabila bentuk badan jarog dan koja yang diinginkan telah tercapai. Untuk menghasilkan bentuk jarog dan koja yang bagus, yaitu melebar di bagian bawah, maka kerapatan rongga jalinan semakin bawah dibuat semakin melebar. Jika ukuran kerapatan rongga mulai dari bagian atas sampai dengan bawah sama, maka bentuk jarog dan koja akan lurus. Bentuk demikian dinilai kurang artistik dan kurang bagus. Untuk memperindah bentuk jarog dan koja pada ujung kiri-kanan bawah dibuat hiasan berupa rumbai-rumbai dengan variasi yang menarik. Hiasan dapat berupa jalinan kulit kayu itu sendiri atau dari batok kelapa yang sudah dibentuk dan dihaluskan.

Pembuatan jarog memerlukan waktu lebih lama dibandingkan dengan koja karena jumlah tali lusi lebih banyak. Begitu juga bentuk jarog lebih besar daripada koja. Sebuah jarog dan koja jika dikerjakan terus-menerus akan selesai dalam beberapa jam. Namun jarang terjadi seorang pembuat jarog dan koja mengerjakan secara terus-menerus. 
Pekerjaan membuat jarog dan koja sering diselingi dengan mengerjakan pekerjaan rumah, atau mereka menghentikan pembuatan jarog atau koja karena rasa jenuh dan bosan. Lain halnya jika pembuatan jarog dan koja berdasarkan pesanan. Mereka akan mengerjakannya secara sungguh-sungguh untuk memenuhi waktu pemesanan.

\section{Pola Distribusi}

Para pengrajin jarog dan koja membuat jarog dan koja selain untuk digunakan sendiri, mereka pun membuat jarog dan koja untuk dijual. Penjualan jarog dan koja hasil buatan sendiri terdorong adanya peluang. Peluang tersebut berupa orang-orang di luar Baduy yang datang ke Baduy Panamping dan meminati tas tersebut sebagai cinderamata. Selain itu di daerah Baduy Panamping, khususnya yang berdekatan dengan Ciboleger terdapat beberapa penduduk yang rumahnya dijadikan galeri tempat menjual kerajinan khas Baduy.

Terdapat beberapa cara yang dilakukan oleh pengrajin jarog dan koja dalam menjual hasil karyanya. Para pengrajin jarog dan koja yang rumahnya sering dijadikan tempat menginap oleh tamu, akan menyimpan jarog dan koja di rumahnya. Jarog dan koja akan dikeluarkan atau ditawarkan jika tamu yang menginap membutuhkan jarog dan koja. Terjadi transaksi tawar-menawar, apabila harga sudah sepakat maka pembayaran akan dilakukan setelah transaksi selesai. Jika rumah pengrajin jarang atau tidak pernah diinapi oleh tamu, maka jarog dan koja buatannya akan dipajang di depan rumahnya dengan harapan terdapat tamu yang melewati rumahnya dan tertarik untuk membeli jarog dan koja yang dipajang. Jika masih tidak laku, jarog dan koja akan dititipkan ke rumah tetangga yang menjual aneka cinderamata. Jarog dan koja yang dititipkan akan dibayar jika sudah laku terjual.
Jumlah jarog dan koja yang dibuat cukup banyak tersimpan di rumah pengrajin. Apabila tamu yang menginap tidak ada, sebagian akan dititipkan kepada tetangga yang menjual aneka cinderamata dan beberapa buah akan dititipkan ke pedagang cinderamata di pasar Ciboleger. Pembayaran jarog dan koja tersebut dilaksanakan apabila jarog dan koja laku dijual. Terdapat pula penjualan jarog dan koja berdasarkan pesanan. Pemesan akan memesan jarog dan koja lama sebelumnya. Pesanan akan diambil pada saat pemesan datang ke Baduy. Pembayaran akan dilaksanakan pada saat penyerahan jarog dan koja kepada pemesan. Pemesan jarog dan koja biasanya para pedagang barangbarang antik dan cinderamata.

Dengan cara pendistribusian jarog dan koja seperti terurai pada penjelasan sebelumnya, tidak terdapat pedagang kolektor yang menampung jarog dan koja sebanyak-banyaknya. Peran yang ada berupa perantara antara penjual dan pembeli jarog dan koja. Peran ini tidak bersifat permanen melainkan terjadi sesekali ketika pedagang atau pengrajin kehabisan persediaan. Peran perantara ini biasanya dipegang oleh suami atau istrinya. Mereka akan berkeliling mencari jarog dan koja pada pengrajin atau pedagang yang memiliki jarog dan koja berkualitas baik. Perantara tidak terlibat dalam transaksi jual-beli. Keuntungan yang diperoleh adalah kelebihan antara harga jual dari pengrajin dan pembeli. Tidak terdapat aturan mengenai keuntungan yang diperoleh, namun mereka sudah kenal betul etika berjualan dengan membagi keuntungan kepada penjual dan perantara. Harga jarog lebih mahal dibandingkan koja. Harga jarog sekarang yakni sekitar 150-200 ribu rupiah sedangkan koja antara 75-100 ribu rupiah

\section{Pola Konsumsi}

Kini, orang Baduy Panamping, termasuk pengrajin jarog dan koja telah mengenal transaksi jual-beli menggunakan alat tukar uang. Uang yang mereka peroleh 
dari berbagai usaha yang tidak ditabukan (seperti menjual beras dan nasi) akan digunakan untuk memperoleh berbagai kebutuhan yang dibolehkan oleh adat. Mereka dibolehkan menjual kerajinan dan aneka barang khas Baduy kepada para tamu dari luar Baduy yang berkunjung ke Baduy, seperti aneka pakaian khas Baduy, iket kepala, kaos bergambar Baduy, selendang khas Baduy, tempat minum, hiasan tangan khas Baduy, gula merah, dan durian. Khusus kepada sesama pengrajin jarog dan koja, mereka pun terkadang menjual tali kulit pohon teureup.

Uang yang mereka peroleh dari penjualan aneka barang akan disimpan untuk digunakan berbagai keperluan. Keperluan yang biasa mereka beli adalah beras, lauk-pauk, pakaian, telepon genggam, dan pulsanya. Uang hasil penjualan jarog dan koja bisa juga digunakan untuk membekali atau membantu saudara-saudaranya baik yang berada di dalam atau di luar perkampungan Baduy. Jika bahan baku berupa tali kulit teurep kurang karena persediaan habis, maka uang hasil penjualan akan dibelikan juga tali kulit teureup kepada pengrajin lain. Mereka pun mengenal menabung dengan cara menyimpan uang sisa belanja di rumah.

\section{A spek Budaya dalam Sistem Ekonomi Pembuat Jarog dan Koja}

Kebudayaan adalah segala sesuatu yang terdapat pada masyarakat ditentukan oleh kebudayaan yang dimiliki oleh masyarakat itu atau yang disebut dengan cultural-determinism, yaitu kepastian kebudayaan pada masyarakat tertentu. Kebudayaan dipandang sebagai sesuatu yang turun-temurun dari satu generasi ke generasi lain, yang kemudian disebut sebagai superorganik. Kebudayaan adalah proses adaptasi dinamis dari manusia dalam mempertahankan kelangsungan hidupnya.

Sistem ekonomi pengrajin jarog dan koja merupakan bahasan yang menarik. Bukan hanya dilihat dari kemunculan sistem ekonomi pada pekerjaan yang dilakukan, tetapi terdapat pertahanan kebiasaan secara turun-temurun dan telah berlangsung lama.

Orang-orang di luar Baduy yang baru pertama kali melihat jarog dan koja akan langsung bertanya tentang asal kantong tersebut. Kepenasaran tersebut karena bentuk jarog dan koja yang unik. Orang yang sudah mengetahui kantong tersebut akan langsung mengetahui bahwa kantong tersebut merupakan kantong khas buatan orang Baduy. Hal ini menunjukkan bahwa jarog dan koja merupakan "trade mark" Baduy yang mungkin tidak dimiliki oleh suku bangsa lainnya di Indonesia. Sekalipun demikian, orang-orang Baduy tidak mengklaim bahwa jarog dan koja merupakan milik mereka yang tidak terdapat di daerah lain. Mereka hanya patuh untuk membuat jarog dan koja berdasarkan kebiasaan dan pola-pola yang diturunkan oleh pendahulu mereka.

Sikap untuk terus melanjutkan pembuatan jarog dan koja dari para pendahulu mereka merupakan kepatuhan terhadap hal-hal baik yang disampaikan oleh para orang tuanya. Dalam menerima sesuatu dari para pendahulu mereka, mereka tidak pernah mengkritisi berupa pertanyaan atau tanggapan. Mereka sangat percaya bahwa sesuatu yang disampaikan oleh para pendahulu merupakan hal yang baik yang tidak perlu diragukan lagi kebenarannya, apalagi jika hal tersebut berkaitan dengan kebutuhan hidup.

Pola-pola penurunan keterampilan membuat jarog dan koja yang diterima dari para pendahulu mereka akan disampaikan kembali kepada generasi berikutnya, khususnya anaknya. Teknik penyampaian keterampilan pun dilakukan dengan pola tradisional yang lebih menekankan pada aspek mencontohkan secara tidak formal. Anak-anak mereka akan diajak dan diperlihatkan seluruh proses pembuatan jarog dan koja dari mulai mengambil kulit pohon teureup sampai dengan pembuatan jarog dan koja. Mereka pun akan memperlihatkan dan mencontohkan hal- 
hal yang perlu dikerjakan dengan mempertimbangkan unsur usia dan kemampuan anaknya. Hasil penurunan keterampilan secara demikian akan menjadikan penguasaan keterampilan tiap anak mereka tidak sama. Hanya kepada anak-anak yang menerima keterampilan secara sungguh-sungguhlah, mereka akan memberikan tingkat keterampilan tambahan agar jarog dan koja yang dihasilkan baik.

Dalam memberikan contoh kepada anak-anaknya, mereka sangat menekankan pada pengerjaan sesuatu dengan sebaikbaiknya, tidak pernah memberi pepatah bahwa jarog dan koja yang bagus mempunyai nilai jual yang tinggi karena diminati. Jika kemudian para pengrajin jarog dan koja menjadikan hasil karyanya sebagai barang dagangan, semata-mata karena adanya peluang dari tamu yang datang untuk membeli hasil karyanya. Jika kemudian para pengrajin ini terus membuat dan menjual jarog dan koja-nya, karena sudah dirasakan keuntungannya. Dengan uang hasil penjualan jarog dan koja dirasakan sebagai bantuan keuangan dalam memenuhi kebutuhan hidup. Mereka tidak bisa menggantungkan kebutuhan uang hanya dari hasil pertanian, apalagi mereka dilarang untuk menjual padi atau beras.

Para pengrajin jarog dan koja serta penduduk lain yang memiliki usaha sampingan sebagai penjual cinderamata akan memiliki uang lebih banyak dibandingkan dengan penduduk yang hanya memiliki usaha bertani di huma. Bentuk rumah para pengrajin serta pakaian yang digunakan tidak memperlihatkan kelebihan jumlah uang yang dimilikinya. Kelebihan uang yang mereka miliki kebanyakan ditabung untuk digunakan jika diperlukan, atau digunakan untuk membeli beras guna dimakan sehari-hari. Padi hasil huma disimpan sebanyak mungkin dan digunakan sehemat mungkin agar kelak dapat diwariskan kepada anak-anaknya. Sebagai bentuk hubungan sosial yang baik, para pengrajin jarog dan koja akan memberikan jarog dan koja buatannya kepada tetangga yang memerlukan. Caracara yang demikian dapat menghindarkan konflik akibat perbedaan strata sosial di bidang kekayaan.

\section{PEN UTU P}

Tidak dapat dipungkiri, dengan perkembangan zaman dan perubahan waktu telah terjadi perubahan tingkat kebutuhan. Kini, mereka membutuhkan uang sebagai alat pembelian beberapa kebutuhan. Cara perolehan uang yang sangat menggantungkan kepada hasil pertanian selain padi yakni buah-buahan dan hasil pertanian lainnya tidak dapat diandalkan lagi. Pertambahan penduduk menjadikan ketersediaan lahan semakin berkurang dan hasil yang diperoleh pun berkurang.

Upaya mencari sumber uang dengan menjual jarog dan koja merupakan salah satu pilihan yang dapat memenuhi kebutuhan akan uang. Uang yang mereka peroleh dapat digunakan untuk membeli beras dan lauk-pauk. Dengan membeli beras, padi di leuit tidak terambil dan tetap utuh. Uang pun dapat digunakan untuk membantu keluarga yang membutuhkan.

Hal lain yang lebih menarik dari keberadaan jarog dan koja yang dibuat oleh orang Baduy ini dikaitkan dengan konsep pelestarian alam. Problematika sampah akibat penggunaan plastik secara besar-besaran dianggap penyumbang limbah kantong plastik terbesar. Kantong plastik yang terpendam dalam tanah merusak kesuburan tanah serta banjir akibat sumbatan kantong plastik di got, selokan, dan sungai mulai menjadi bibit bencana nasional. Pemerintah secara bertahap sampai harus mengeluarkan peraturan ke arah pelarangan penggunaan kantong plastik dalam berbagai aktivitas. Orang Baduy sudah memiliki kearifan tradisional dalam pelestarian alam. Mereka membuat kantong berupa jarog dan koja dari bahan alami tanpa merusak pohon teureup yang hanya diambil kulitnya. Kantong yang sudah tidak terpakai dapat 
dibuang di atas tanah tanpa khawatir merusak kesuburan tanah, malahan sebaliknya dapat menyuburkan tanah.

Keberadaan jarog dan koja selain dapat meningkatkan kemampuan ekonomi pengrajinnya, dapat juga dijadikan alternatif atas problematika penggunaan kantong plastik.

\section{DAFTAR SUMBER}

\section{Makalah, Jurnal}

Ahimsa-Putra, H.S. "Tradisi/Adat Istiadat: Pemahaman dan Penerapannya", Makalah dalam Diklat Tenaga Peneliti Tingkat Lanjutan, Direktorat Tradisi, Jakarta. 2007.

Andayani, Ria. "Sistem Ekonomi Pengrajin Kelom Geulis di Gobras, Kota Tasikmalaya, Provinsi Jawa Barat" dalam Jurnal Patanjala Vol. 7 No. 3. September 2015. Hlm. 477-492.

Intani, Ria. "Konsep Tata Ruang Rumah Tinggal Masyarakat Kuta Desa Karang Paningal Kecamatan Tambaksari Kabupaten Ciamis" dalam Jurnal Patanjala Vol. 5 No. 1. Maret 2013. Hlm. 68-81.

“Kesenian Badawang di Kecamatan Cibiru-Bandung" dalam Jurnal Patanjala Vol. 5 No. 1. Maret 2013. Hlm.186-197.

Kasnodihardjo. "Lebih Jauh Mengenal Metode Pengamatan" dalam Media Litbangkes Vol. II/No. 3/1992.

Rusnandar, Nandang. "Seba, Puncak Ritual Masyarakat Baduy di Kabupaten Lebak Provinsi Banten" dalam Jurnal Patanjala Vol. 5 No. 1. Maret 2013 Hlm.82-98.

"Tradisi Mendirikan Imah Gede dan Rumah Warga di Kasepuhan Sinar Resmi Kabupaten Sukabumi" dalam Jurnal Patanjala Vol. 7 No. 1. Maret 2015. Hlm. 97-112.

\section{Buku}

Darminto, Th.A. 1987.

Aspek Seni Kriya dalam Arus Modernisasi. Jakarta: Departemen Pendidikan dan Kebudayaan.
Departemen Pendidikan Nasional. 2013.

Kamus Besar Bahasa Indonesia. Jakarta: PT Gramedia Pustaka Umum.

Dinas Inkosbudpar Lebak. 2004.

Tradisi Budaya Masyarakat Baduy dan Cisungsang serta Peninggalan Sejarah Situs Lebak Subedug. Lebak.

Harsojo, 1982.

Pengantar Antropologi. Bandung: Bina Cipta.

Koentjaraningrat, 1990

Kebudayaan Mentalitas dan

Pembangunan. Jakarta: PT Gramedia. ,1990.

Sejarah Antropologi II. Jakarta: UIPress.

Saebani, Beni Ahmad. 2012.

Pengantar Antropologi, Bandung: CV.Pustaka Setia

Sugih Biantoro, Genardi Atmadiredja. "Bidai:Seni Kriya Menembus Pasar Malaysia", Emmed (edt) dalam Bunga Rampai Keraifan Lokal dan Lingkungan. 2013. Hlm. 73-88.

Suhada, 2003

Masyarakat Baduy dalam Rentang Sejarah. Serang: Dinas Pendidikan Provinsi Banten.

\section{Internet}

www.biem.co/read/2015/05/18/98/sebabaduy-2015-menjaga-lingkungan-denganbudaya.

Diakses tanggal 02 Januari 2016 Jam 19.00 